\title{
E-Commerce: Marketing Gift Fruit on the Internet ${ }^{1}$
}

\section{Robert L. Degner and Kimberly L. Morgan ${ }^{2}$}

Florida entrepreneurs have a long and colorful history of selling fruit, primarily citrus, to other states. Early visitors were impressed with the colorful, aromatic, and succulent fruits that were widely available in Florida during the fall, winter, and spring months, when other regions of the United States were in the grip of winter. Visitors frequently took fruit back home with them or shipped fruit by mail for gifts and special occasions. The widespread availability of citrus fruits in late fall and winter also coincided with the Thanksgiving and Christmas holiday seasons, which stimulated the development of Florida's gift fruit industry.

In recent years, the Internet has emerged as a potent marketing tool for gift fruit because it gives access to hundreds of gift fruit vendors' websites. The Internet also offers other advantages for marketing gift fruit, such as providing virtually unlimited geographic coverage for items with reasonably long shelf lives that are easy to ship. From a business management standpoint, the Internet creates marketing opportunities for firms of all sizes due to low operating costs. Online ordering allows orders to be processed rapidly and efficiently. In addition, electronically processed orders can be automatically archived for future analyses and marketing efforts. Unfortunately, many retail websites do a poor job of providing customers with a pleasant online shopping experience, which gift fruit vendors should view as a challenge to adopt customer-centric marketing plans to increase their e-commerce and to develop long-term customer loyalty.

There are two objectives of this paper: (1) to examine and critique the current Internet marketing practices of gift fruit shippers, and (2) to provide suggestions for improved Internet marketing efforts. Internet sites for gift fruit vendors were reviewed using the term "gift fruit" as the keyword for all online searches, with two web portals being targeted: http://www.FruitSearch.com and http://www.FGFSA.com (the latter is the website for the Florida Gift Fruit Shippers Association, the venerable trade association for Florida's gift fruit industry).

A total of 167 unique, relevant, and active websites were accessed. All marketed gift fruit, but not all offered online ordering. More than a dozen parameters were identified and evaluated. The presence or absence of each parameter was observed by reviewing each firms website, and the results

1. This is EDIS document FE430, a publication of the Department of Food and Resource Economics, Florida Cooperative Extension Service, UF/IFAS, University of Florida, Gainesville, FL. Published February 2004. This is an abridged version of the original document published in 2000, which is available online at http://agmarketing.ifas.ufl.edu. Please visit the EDIS website at http://edis.ifas.ufl.edu.

2. Robert L. Degner, Professor, and Kimberly L. Morgan, Economic Analyst, Florida Agricultural Market Research Center, Department of Food and Resource Economics, Florida Cooperative Extension Service, UF/IFAS, University of Florida, Gainesville, FL. 
tabulated and analyzed in a Microsoft Excel spreadsheet.

The parameters that were judged to affect consumer shopping behavior for gift fruit were enumerated and placed into two broad categories: buyer convenience and buyer assurance. Buyer convenience is key in virtually any kind of transaction (i.e., offer items that meet the buyers needs and make it easy to consummate the sale). Buyer assurance (e.g., providing customer confidence in the integrity of the vendor, the product offered, and successful buying transactions) is critical, particularly in the E-commerce environment of the Internet.

Two important services that online gift fruit companies should provide are buyer convenience and buyer assurance. Buyer convenience includes offering a variety of packaging and payment options for all types of occasions via professionally designed websites. Buyer assurance includes offering online ordering security, product guarantees, and reliable shipping options.

This study had several suggestions for improving existing Internet sites and establishing new sites. First, Internet-based companies should strive to improve their Internet customer service to improve customer satisfaction. Second, firms need to provide online security to protect itself and its customers from Internet fraud. Finally, firms must provide customer assurance of company credibility by offering service guarantees and product quality.

Online gift fruit customers are attracted by strategies that simplify the buying process. Firms should offer a wide variety of fresh and processed items that can be packaged in a variety of attractive ways, and maximize customer satisfaction by offering online ordering capabilities, toll-free ordering access, and real time customer service.

\section{Bibliography}

Degner, Robert L., and Kimberly L. Morgan. 2000. E-commerce: Marketing gift fruit on the internet. 2000 Proceedings of the Florida State Horticultural Society 113: 49-52. Full text available at http://agmarketing.ifas.ufl.edu.
Khan, Mickey Alam. 2000. Rise in users sends online sales soaring. DM News. Retrieved March 31, 2000, from

http://www.dmnews.com/cgi-bin/index.cgi.

Richard, Eric 2000. E-retailers get savvy about e-customers. DM News. Retrieved April 11, 2000, from http://www.dmnews.com/cgi-bin/index.cgi.

White, Gregory K. 1999. Catalog specialty food buyers' computer usage and purchasing activity: A case study. Working Paper 99-03, The Retail Food Industry Center, University of Minnesota, St. Paul, MN (May). Available at http://agecon.lib.umn.edu/cgi-bin/ pdf_view.pl?paperid=1697\&ftype=.pdf.

White Gregory K. 2000. Consumable products: Building consumer loyalty online. Active Media Research. Available at http://www.activemediaresearch.com/ consumable_products.html\#toc. 